\title{
Frequency of enteroparasitic infections and serum positivity for Toxocara spp. in children from a public day care center in Southern Brazil
}

\author{
G. M. S. Araújo * (D), D. L. Walcher ${ }^{b}$ (D), I. F. Previtalia (D), L. M. Lehman (D), M. P. Costa $^{\text {(D), }}$ \\ L. O. Susin C (D), L. F. C. Avila ${ }^{\text {(D) }}$ and C. J. Scaini ${ }^{a}$
}

\begin{abstract}
${ }^{a}$ Laboratório de Parasitologia, Programa de Pós-graduação em Ciências da Saúde, Área Interdisciplinar de Ciências Biomédicas, Faculdade de Medicina, Universidade Federal do Rio Grande - FURG, Rua Visconde de Paranaguá, 102 , Centro, CEP 96203-900, Rio Grande, RS, Brasil

bPrograma de Pós-graduação em Parasitologia, Departamento de Microbiologia e Parasitologia, Universidade Federal de Pelotas - UFPel, Campus Universitário Capão do Leão, CEP 96160-000, Capão do Leão, RS, Brasil

cÁrea de Pediatria, Faculdade de Medicina, Universidade Federal do Rio Grande - FURG, Rua Visconde de Paranaguá, 102, Centro, CEP 96203-900, Rio Grande, RS, Brasil

*e-mail: gabrieladmsaraujo@gmail.com
\end{abstract}

Received: May 28, 2018 - Accepted: February 12, 2019 - Distributed: May 31, 2020

\begin{abstract}
Introduction: Day care centers play an important social role in children's early education and development. The objective of this study was to investigate the frequency of intestinal parasitic infections and infection with Toxocara spp. in children from a day care center in the city of Rio Grande, Rio Grande do Sul, Brazil. Methods: The study was conducted using fecal samples from 50 children, ages three to six years, using Ritchie, Faust, Rugai, and Kinyoun's techniques. A closed and structured epidemiological questionnaire was used to collect data from the parents/guardians of the children. Serological studies for detection of antibodies to Toxocara spp. by immunoenzymatic assays using Toxocara excretion and secretion antigen (TES) were conducted on sera collected from 41 children. Results: The frequency of enteroparasites was $18 \%$, with $43.9 \%$ of the children testing seropositive for Toxocara spp. Low family income and low literacy levels of parents/guardians were common factors between the families of the parasite-positive children. For the children who tested positive for Toxocara spp., most of the parents/guardians reported using only water for sanitizing raw vegetables and fruits. Conclusions: The high seropositivity rates for Toxocara spp. indicate that children were exposed to this parasite, and it is important to reduce the risk of infection. In addition, the seropositivity for enteroparasites and the interviews with the parents/guardians indicate the need to educate the studied population regarding the modes of intestinal parasite transmission and the prophylactic measures needed to prevent their dissemination.
\end{abstract}

Keywords: intestinal parasites, toxocariasis, day care.

\section{Frequência de enteroparasitos e de soropositividade para Toxocara spp. em crianças de uma creche pública do Sul do Brasil}

\begin{abstract}
Resumo
Introdução: As creches desempenham um importante papel social na educação e desenvolvimento inicial das crianças. O objetivo deste estudo foi investigar a frequência de infecções parasitárias intestinais, além de infecção por Toxocara spp. em crianças de uma creche na cidade do Rio Grande, Rio Grande do Sul, Brasil. Métodos: Para o estudo, foram coletadas amostras fecais de 50 crianças de três a seis anos, analisadas pelas técnicas de Ritchie, Faust, Rugai e Kinyoun, sendo aplicado um questionário epidemiológico fechado e estruturado aos pais/responsáveis das crianças. Também foi realizada uma pesquisa sorológica de anticorpos para Toxocara spp. em 41 crianças, pelo ensaio imunoenzimático, associado ao antígeno de excreção e secreção (ES), com soros pré-adsorvidos com antígeno somático de Ascaris lumbricoides. Resultados: A frequência de enteroparasitos foi de $18 \%$, enquanto que $43.9 \%$ das crianças foram soropositivas para Toxocara spp.. Baixa renda familiar e baixo nível de alfabetização dos pais/responsáveis foram fatores comuns entre as famílias das crianças parasitadas. A maioria dos pais ou responsáveis das crianças, com diagnóstico positivo para enteroparasitos ou para Toxocara spp., relatou utilizar apenas água para a higienização de verduras e frutas. Conclusões: As altas taxas de soropositividade para Toxocara spp. indicam que as crianças foram expostas a esse parasito, sendo importante minimizar o risco de infecção. Além disso, a positividade de 18\% para enteroparasitos e os dados obtidos com as entrevistas realizadas com os pais ou responsáveis demonstram a necessidade da realização de trabalhos com a população estudada que visem a divulgação sobre as parasitoses intestinais, especialmente sobre medidas profiláticas especificas.
\end{abstract}

Palavras-chave: parasitos intestinais, toxocaríase, creche. 


\section{Introduction}

With expanding urbanization and the rapid increase in the number of women in the workplace, day care centers are playing an important role in the early social and educational development of children (Biscegli et al., 2009). Apart from being critical in children's physical and mental development, these institutions provide one of the first environments where children are outside of their homes and are first exposed to parasitic infections (Gurgel et al., 2005).

Most epidemiological studies conducted in day care centers refer to the precarious health and living conditions of the population studied but do not report the sanitary conditions of the day care centers (Gurgel et al., 2005; Gonçalves et al., 2011). Nevertheless, these sites have been considered important sources of intestinal parasitic infections (Silva et al., 2010; Gonçalves et al., 2011). Intestinal parasites are an important public health concern that affects approximately $25 \%$ of the world population, especially in the developing countries (WHO, 2017).

An important parasitic infection in humans is toxocariasis, a worldwide zoonotic infection that is often neglected (Moreira et al., 2014). This tissue parasitic infection mainly affects children from families with low social class and inadequate hygiene habits (Souza et al., 2011). Until now, no studies have been conducted on the prevalence of toxocariasis in day care children. Noticeably, these children belong to an age group that has been shown to have high seroprevalence rates and are known to be more susceptible to disease development (Smith and Noordin, 2006; Magnaval et al., 2001). Most studies have involved children of a wide age group (0-12 years) (Marchioro et al., 2015). The main etiological agents of toxocariasis are nematodes that belong to the Toxocara spp. family and are intestinal parasites of dogs and cats. The primary modes of transmission to humans include the consumption of vegetables, fruits, and water contaminated with embryonated eggs of the parasite and by geophagy (Maizels et al., 2006). Consumption of uncooked or undercooked meat potentially contaminated with Toxocara spp. also poses a risk of toxocariasis (Ma et al., 2018).

This study aimed at investigating the parasitological profile of children in a day care center with adequate sanitary conditions, located in the extreme south of Brazil.

\section{Methods}

\subsection{Research participants and study site}

This study was conducted using samples collected from three to six-year-old children attending a day care center located in the city of Rio Grande - RS, Brazil. The selected center operates as a full day care and has a drinking water supply as well as medical and dental care facilities available twice a week. It also has facilities for garbage collection, sewage treatment, and sanitation. The water tank is cleaned twice a year using a chlorinated solution. The nursery has an enclosed sand playground and is walled to prevent domestic animals from having access to the premises.

\subsection{Experimental design}

This cross-sectional descriptive study was carried out between August and November of 2016. All 50 children who attended the day care during this period participated in this study, with consent from their parents or guardians. However, serological research was performed on only 41 children, since 9 children refused to give their blood sample.

\subsection{Epidemiological data}

The parents or guardians of the children answered a closed and structured questionnaire regarding their knowledge of intestinal parasitoses and sociodemographic data was also collected. The questionnaires were typed twice using the EpiData 3.1 program.

\subsection{Diagnosis of intestinal parasitoses}

Stool samples were collected from the participating children on three alternate days. Fresh stool samples were stored in previously identified sterile vials; the vials were labeled with the same number as the questionnaire for each child and were taken to the Laboratory of Parasitology, Faculty of Medicine of the Federal University of Rio Grande (FURG), for immediate processing.

Samples were processed using the techniques of Ritchie (1948), Faust et al. (1938), Rugai et al. (1954). Each sample was examined in triplicate and studied under an optical microscope at $100 \times$ and $400 \times$ magnifications. To investigate the presence of Cryptosporidium spp., auramine-stained stool samples were screened for oocytes under a fluorescence microscope at $400 \times$ magnification. Kinyoun alcohol-acid staining was used to confirm the presence of the oocytes by observing the samples at $1000 \times$ magnification under an optical microscope.

\subsection{Serology for human toxocariasis}

The Toxocara canis excretory-secretory antigen (TES) was obtained from Toxocara canis larvae, according to the methodology described by Savigny (1975) and Maizels et al. (1992). The somatic antigen of Ascaris lumbricoides was produced from $A$. lumbricoides females obtained from a naturally infected patient from the University Hospital at the FURG, following the methodology of Souza et al. (2011). Antigen protein concentration was determined by the bicinchoninic acid (BCA) assay (Smith et al., 1985). Serum samples pre-adsorbed with somatic antigen from A. lumbricoides (Camargo et al., 1992) were evaluated by TES-ELISA for the detection of Toxocara-specific immunoglobulin G (IgG), following the methodology of Santos et al. (2015).

\subsection{Blood count}

A hemogram of each collected blood sample was performed at the Birck Ltda Laboratory in the city of Rio Grande, RS, using an automated process that employs 18 parameters complemented with microscopic observation. 


\section{Ethics}

This study was approved by the Research Ethics Committee of the Health Area of the Federal University of Rio Grande (Technical advice: 70/2015).

\section{Results}

The overall observed frequency of enteroparasites was $18 \%(9 / 50)$. Of the total number of enteroparasites evaluated using the techniques of Faust and Ricthie, $10 \%$ were identified as Giardia lamblia cysts, $6 \%$ were geohelminth eggs of Ascaris lumbricoides and Trichuris trichiura, and $2 \%$ were Enterobius vermicularis eggs. No Cryptosporidium oocytes were detected using Kinyounresistant alcohol-acid staining. Similarly, Strongyloides stercoralis larvae were not detected using the technique described by Rugai, Mattos, and Brisola.

Of the total number of children included in the study, 43.9\% (18/41) tested serologically positive for Toxocara-specific IgG. A positive correlation between Toxocara spp. and enteroparasites was observed in three children $(7.3 \%)$. In relation to blood eosinophilia, three children had $6 \%$ higher eosinophil counts than the remaining group. However, these three children did not test positive for Toxocara spp. or other enteroparasites.

The sociodemographic data obtained from the parents or guardians of the children were studied, with $42 \%$ $(21 / 50)$ of families having at least one minimum wage monthly income, $84 \%(42 / 50)$ of the families lived in their own residence, and the average density per household was 4.5 people. Regarding the possible risk factors, all families indicated that they had adequate facilities for water treatment, sanitation, and garbage collection at their residence. Also, it was reported that their children consumed fruits and vegetables, but $68 \%$ (34/50) of families only use water for cleaning these foods. It is important to mention that $37.5 \%$ of the parents or guardians of the children who tested positive for enteroparasites answered that they neither filter nor boil the water before consumption.

In addition, the responses to the questionnaire suggested that $40 \%(20 / 50)$ of the children had regular contact with soil, 20\% (10/50) practiced onychophagia, and 8\% (4/50) practiced geophagy. In relation to their contact with pets that could be definitive hosts of $T$. canis, it was observed that $75.6 \%(31 / 41)$ of the children had regular contact with dogs and $31.7 \%$ (13/41) had contact with cats. Among the seropositive children for Toxocara spp., $66.7 \%$ had contact with dogs (Table 1).

Table 1. Possible risk factors for infection and seropositivity for Toxocara spp. and other enteroparasites in children attending a day care center in Rio Grande do Sul, Brazil.

\begin{tabular}{|c|c|c|c|c|c|}
\hline \multirow{2}{*}{ Variables } & & \multicolumn{2}{|c|}{$\begin{array}{c}\text { Enteroparasites } \\
(n=8) \\
\end{array}$} & \multicolumn{2}{|c|}{$\begin{array}{c}\text { Toxocara spp. } \\
(n=18)\end{array}$} \\
\hline & & Positive & $(\%)$ & Positive & $(\%)$ \\
\hline \multicolumn{6}{|l|}{ Onicophagy } \\
\hline & Yes & 01 & $(12.5)$ & 04 & $(22.2)$ \\
\hline & No & 07 & $(87.5)$ & 14 & $(77.8)$ \\
\hline \multicolumn{6}{|l|}{ Geophagy } \\
\hline & Yes & - & - & - & $(-)$ \\
\hline & No & 08 & $(100.0)$ & 18 & $(100.0)$ \\
\hline \multicolumn{6}{|l|}{ Contact with soil } \\
\hline & Yes & 02 & $(25.0)$ & 08 & $(44.4)$ \\
\hline & No & 06 & $(75.0)$ & 10 & $(55.6)$ \\
\hline \multicolumn{6}{|l|}{ Treatment of drinking water } \\
\hline & Filtered & 02 & $(25.0)$ & 06 & $(33.3)$ \\
\hline & Boiled & 03 & $(37.5)$ & 02 & $(11.1)$ \\
\hline & None & 03 & $(37.5)$ & 10 & $(55.6)$ \\
\hline \multicolumn{6}{|l|}{ Consumption of fruits and/or vegetables } \\
\hline & Yes & 08 & $(100.0)$ & 18 & $(100.0)$ \\
\hline \multicolumn{6}{|l|}{ Hygiene of fruits and vegetables } \\
\hline & Vinegar & 02 & $(25.0)$ & 02 & $(11.1)$ \\
\hline & Sanitary water & 02 & $(25.0)$ & 03 & $(16.7)$ \\
\hline & Water & 04 & $(50.0)$ & 13 & $(72.2)$ \\
\hline \multicolumn{6}{|c|}{ Consumption of raw or undercooked meat } \\
\hline & Yes & - & - & 01 & $(5.6)$ \\
\hline & No & - & - & 17 & $(94.4)$ \\
\hline \multicolumn{6}{|l|}{ Contact with dogs } \\
\hline & Yes & - & - & 12 & $(66.7)$ \\
\hline & No & - & - & 06 & $(33.3)$ \\
\hline \multicolumn{6}{|l|}{ Contact with cats } \\
\hline & Yes & - & - & 07 & $(38.9)$ \\
\hline & No & - & - & 11 & $(61.1)$ \\
\hline
\end{tabular}


The parents' awareness regarding intestinal parasitoses, $94 \%$ said they had minimal knowledge about the topic and that the most frequent symptoms for intestinal parasitoses were abdominal pain $(24 \%)$, anorexia $(18 \%)$, diarrhea $(10 \%)$, vomiting $(10 \%)$, and anal pruritus $(8 \%)$. However, $58 \%$ of the parents answered that they were not aware of the symptomatology associated with these parasites and $72 \%$ of the parents thought that some of the parasitoses can be asymptomatic. In addition, $16 \%$ of the parents believed that one cannot get affected by the same parasite following antiparasitic treatment. Although most parents or guardians reportedly had some knowledge about major intestinal parasites, $74 \%$ said that they still lack information on the subject.

\section{Discussion}

The findings of this investigative study may help in understanding the epidemiology of parasitic infections of children attending day care centers, in addition to being fundamental in monitoring their health and sanitary conditions. It is important to emphasize that the children involved in this study belonged to the age group considered to be the most susceptible to the development of the classic form of toxocariasis (Magnaval et al., 2001). The observed seropositivity for Toxocara spp. (43.9\%) in the children from this study is in agreement with the rates observed by various philanthropic organizations, public and private schools in Bahia (47\% to $48.8 \%$ ), and Rio Grande do Sul (50.6\%) (Mendonça et al., 2012; Schoenardie et al., 2013), being higher than in some other studies in Paraná (25 to 36.8\%) (Mattia et al., 2011; Marchioro et al., 2011; Marchioro et al., 2015) and in São Paulo (15.5\%) (Cassenote et al., 2014). It is important to point out that seroprevalence varies according to the target population, region studied, and diagnostic methods employed. In the aforementioned studies, TES-ELISA(IgG) was used to test sera pre-adsorbed with the somatic antigen from Ascaris sp., which is considered the standard methodology in regions with polyparasitism (Elefant et al., 2006).

The frequency of other intestinal parasites in the children from this study was $18 \%$, which is much lower than that observed in other studies performed in day care centers in Brazil (29.3\% to 66.4\%) (Carvalho et al., 2006; Moreira et al., 2014; WHO, 2017). This difference can be justified by the fact that the nursery investigated in the current study had adequate sanitary facilities, such as basic sanitation, drinking water, sewage and garbage collection, as well as medical care. It is important to note that most of the previous studies did not report the sanitary conditions of the nurseries (Carvalho et al., 2006; Moreira et al., 2014; WHO, 2017), although all suggested that these centers are important sources of intestinal parasitic infection (Moreira et al., 2014; WHO, 2017).

Of all the relevant literature reviewed, only the study by Berne et al. (2012), reported that the nursery they investigated had satisfactory sanitary conditions and showed a high prevalence of enteroparasites at $64.2 \%$.
The authors suggested that this prevalence may be due to poor hygiene conditions and basic sanitation of the researched population. This may explain the differences in their findings and that of the present study, which revealed adequate sanitary conditions of the population, despite the registry of enteroparasitoses. The low seropositivity for the geohelminths A. lumbricoides (2\%) and T. trichiura (4\%) in children are justified by the adequate sanitary conditions of the nursery studied. This assertion is reinforced by the fact that none of the 12 nursery workers were seropositive for these geohelminths (unpublished data); hence these professionals could not be the sources of infection (Nolla and Cantos, 2005).

Giardia lamblia was the most common pathogenic protozoan parasite diagnosed in the children (10\%), and Cryptosporidium spp. were not identified in the studied population. Water, including treated water, is the main vehicle for the transmission of G. lamblia cysts and oocysts of Cryptosporidium spp. (Ehsan et al., 2015). Thus, the consumption of unfiltered or non-boiled water, observed in $37.5 \%$ of the children's families, may constitute a source of infection for these parasites.

Regarding sociodemographic conditions, low literacy levels amongst parents or guardians and low family income were directly correlated to the seropositivity for Toxocara spp. and enteroparasites. These data corroborate the findings of previous studies that showed intestinal parasitoses and toxocariasis (Souza et al., 2011; Vasconcelos et al., 2011; Santos et al., 2015) to be more prevalent in families with lower literacy levels and belonging to lower social classes. Thus, it is important that parents seek more information about the transmission of these parasites (Almeida et al., 2012), especially pertaining to the consumption of poorly washed fruits and vegetables (Vasconcelos et al., 2011), since it was observed that the majority of the parents or guardians sanitized their food only with water and not with any food disinfectants.

Among the potential risk factors for Toxocara spp. infection, contact with dogs and soil were the most frequent. Contact with dogs has been a widely demonstrated factor in epidemiological studies of toxocariasis and enteroparasitic infections (Macpherson, 2013; Cassenote et al., 2014; Santos et al., 2015, Curi et al., 2017; Jeske et al., 2018). Although the day care was walled and fenced in, it is quite possible to contaminate the soil with parasites through animal feces from outside of the day care facility.

The knowledge of the parents/guardians of the children regarding intestinal parasitoses was adequate. However, in relation to the symptomatology caused by the main enteroparasites, this knowledge was insufficient. The implementation of educational campaigns (Almeida et al., 2012) and assistance programs (Santarém et al., 2011) are fundamental to avoid or minimize the prevalence of these parasitoses in this population.

This study demonstrates that the high rate of seropositivity for Toxocara spp. indicates that the tested children were exposed to this parasite. The age group of children who generally attend day care centers is the most susceptible to 
developing human toxocariasis. Hence, it is essential that the risk of infection be assessed and minimized. In addition, $18 \%$ seropositivity for other enteroparasites and interviews with the parents or guardians demonstrate the need to educate this population about the modes of transmission of intestinal parasites and also the prophylactic measures to prevent the occurrence of these infections.

\section{Acknowledgments}

We would like to thank the patients who participated in the research as well as the day care center and their professionals for their support.

\section{References}

ALMEIDA, I.A., BERNE, M.E.A. and VILLELA, M.M., 2012. Prevalência de enteroparasitoses em crianças internadas em unidades pediátricas de hospitais em Pelotas, Rio Grande do Sul, Brasil-nota prévia. Revista Sodebras., vol. 8, pp. 84.

BERNE, A.C., SCAINI, C.J., VILLELA, M.M., PEPE, M.S., HAUPENTHAL, L.E., GATTI, F. and BERNE, M.E.A., 2012. Presença de coccídios e outros enteroparasitos em uma população de crianças no município de Rio Grande, Rio Grande do Sul, Brasil. Revista de Patologia Tropical, vol. 41, no. 1, pp. 93-96. http://dx.doi.org/10.5216/rpt.v41i1.17752.

BISCEGLI, T.S., ROMERA, J., CANDIDO, A.B., SANTOS, J.M., CANDIDO, E.C.A. and BINOTTO, A.L., 2009. Estado nutricional e prevalência de enteroparasitoses em crianças matriculadas em creche. Revista Paulista de Pediatria : Orgao Oficial da Sociedade de Pediatria de Sao Paulo, vol. 27, no. 3, pp. 289-295. http://dx.doi.org/10.1590/S0103-05822009000300009.

CAMARGO, E.D., NAKAMURA, P.M., VAZ, A.J., SILVA, M.V., CHIEFFI, P.P. and MELO, E.O., 1992. Standardization of dot-ELISA for the serological diagnosis of toxocariasis and comparison of the assay with ELISA. Revista do Instituto de Medicina Tropical de São Paulo, vol. 34, no. 1, pp. 55-60. http:// dx.doi.org/10.1590/S0036-46651992000100010. PMid:1307410.

CARVALHO, T.B., CARVALHO, L.R. and MASCARINI, L.M., 2006. Occurrence of enteroparasites in day care centers in Botucatu (São Paulo State, Brazil) with emphasis on Cryptosporidium sp., Giardia duodenalis and Enterobius vermicularis. Revista do Instituto de Medicina Tropical de São Paulo, vol. 48, no. 5, pp. 269-273. http://dx.doi.org/10.1590/S0036-46652006000500006. PMid:17086314.

CASSENOTE, A.J., LIMA, A.R., PINTO NETO, J.M. and RUBINSKY-ELEFANT, G., 2014. Seroprevalence and modifiable risk factors for Toxocara spp. in Brazilian Schoolchildren. PLoS Neglected Tropical Diseases, vol. 8, no. 5, pp. e2830. http://dx.doi. org/10.1371/journal.pntd.0002830. PMid:24874504.

CURI, N.H.A., PASCHOAL, A.M.O., MASSARA, R.L., SANTOS, H.A., GUIMARÃES, M.P., PASSAMANI, M. and CHIARELLO, A.G., 2017. Risk factors for gastrointestinal parasite infections of dogs living around protected areas of the Atlantic Forest: implications for human and wildlife health. Brazilian Journal of Biology $=$ Revista Brasileira de Biologia, vol. 77, no. 2, pp. 388-395. PMid:27533731.

EHSAN, A., GEURDEN, T., CASAERT, S., PAULUSSEN, J., DE COSTER, L., SCHOEMAKER, T., CHALMERS, R., GRIT, G., VERCRUYSSE, J. and CLAEREBOUT, E., 2015.
Occurrence and potential health risk of Cryptosporidium and Giardia in different water catchments in Belgium. Environmental Monitoring and Assessment, vol. 187, no. 2, pp. 6. http://dx.doi. org/10.1007/s10661-014-4157-z. PMid:25616782.

ELEFANT, G.R., SHIMIZU, S.H., SANCHEZ, M.C.A., JACOB, C.M. and FERREIRA, A.W., 2006. A serological follow-up of toxocariasis patients after chemotherapy based on the detection of $\operatorname{IgG}$, IgA and IgE antibodies by enzume-linked immunosorbent assay. Journal of Clinical Laboratory Analysis, vol. 20, no. 4, pp. 164-172. http://dx.doi.org/10.1002/jcla.20126. PMid:16874812.

FAUST, E.C., D'ANTONI, J.S., ODOM, V., MILLER, M.J., PERES, C., SAWITZ, W., et al., 1938. A critical study of clinical laboratory technics for the diagnosis of protozoan cysts and helminth eggs in feces. I. Preliminary communication. The American Journal of Tropical Medicine and Hygiene, vol. 18, no. 2, pp. 169-183. http://dx.doi.org/10.4269/ajtmh.1938.s1-18.169.

GONÇALVES, A.L.R., BELIZÁRIO, T.L., PIMENTEL, J.B., PENATTI, M.P.A. and PEDROSO, R.S., 2011. Prevalence of intestinal parasites in preschool children in the region of Uberlândia, state of Minas Gerais, Brazil. Revista da Sociedade Brasileira de Medicina Tropical, vol. 44, no. 2, pp. 191-193. http://dx.doi. org/10.1590/S0037-86822011005000022. PMid:21537798.

GURGEL, R.Q., CARDOSO, G.S., SILVA, A.M., SANTOS, L.N. and OLIVEIRA, R.C.V., 2005. Creche: ambiente expositor ou protetor nas infecções por parasitas intestinais em Aracaju, SE. Revista da Sociedade Brasileira de Medicina Tropical, vol. 38, no. 3, pp. 267-269. http://dx.doi.org/10.1590/S003786822005000300014 . PMid:15895183.

JESKE, S., BIANCHI, T.F., MOURA, M.Q., BACCEGA, B., PINTO, N.B., BERNE, M.E.A. and VILLELA, M.M., 2018. Intestinal parasites in cancer patients in the South of Brazil. Brazilian Journal of Biology = Revista Brasileira de Biologia, vol. 78, no. 3, pp. 574-578. http://dx.doi.org/10.1590/15196984.175364. PMid:29185612.

MA, G., HOLLAND, C.V., WANG, T., HOFMANN, A., FAN, C.K., MAIZELS, R.M., HOTEZ, P.J. and GASSER, R.B., 2018. Human toxocariasis. The Lancet. Infectious Diseases, vol. 18, no. 1, pp. 14-24. http://dx.doi.org/10.1016/S1473-3099(17)30331-6. PMid:28781085.

MACPHERSON, C.N.L., 2013. The epidemiology and public health importance of toxocariasis: zoonosis of global importance. International Journal for Parasitology, vol. 43, no. 12-13, pp. 999-1008. http://dx.doi.org/10.1016/j.ijpara.2013.07.004. PMid:23954435.

MAGNAVAL, J.F., GLICKMAN, L.T., DORCHIES, P. and MORASSIN, B., 2001. Highlights of human toxocariasis. Korean Journal of Parasitology, vol. 39, no. 1, pp. 1-11. http://dx.doi. org/10.3347/kjp.2001.39.1.1. PMid:11301585.

MAIZELS, R.M., BLAXTER, M.L., ROBERTSON, B.D. and SELKIRK, M.E., 1992. Parasite antigens, parasite genes. A laboratory manual for molecular parasitology. Camdridge University Press, vol. 70, no. 3, pp. 373-374.

MAIZELS, R.M.I., SCHABUSSOVA, D.M., CALLISTER, G. and NICOL, L., 2006. Molecular biology and immunology of Toxocara canis. In: C. H. HOLLAND and H. V. SMITH, eds. The enigmatic parasite. 1th ed. UK: Cabi Publishing. 324 p. http://dx.doi.org/10.1079/9781845930264.0003

MARCHIORO, A.A., COLLI, C.M., FERREIRA, É.C., VIOL, B.M., ARAÚJO, S.M. and FALAVIGNA-GUILHERME, A.L., 2015. Risk factors associated with toxoplasmosis and toxocariasis 
in populations of children from nine cities in southern Brazil. Journal of Helminthology, vol. 89, no. 4, pp. 428-432. http:// dx.doi.org/10.1017/S0022149X14000212. PMid:24725417.

MARCHIORO, A.A., COLLI, C.M., MATTIA, S., PALUDO, M.L., MELO, G.C., ADAMI, C.M., PELLOSO, S.M. and GUILHERME, A.L.F., 2011. Eosinophilic count and seropositivity for IgG antibodies to Toxocara spp. in children assisted at the public health service. Revista Paulista de Pediatria : Orgao Oficial da Sociedade de Pediatria de Sao Paulo, vol. 29, no. 1, pp. 80-84. http://dx.doi.org/10.1590/S0103-05822011000100013.

MATTIA, S., COLLI, C.M., ADAMI, C.M., GUILHERME, G.F., NISHI, L., RUBINSKY-ELEFANT, G., MARCHIORO, A.A., GOMES, M.L. and FALAVIGNA-GUILHERME, A.L., 2011. Seroprevalence of Toxocara infection in children and environmental contamination of urban areas in Paraná state, Brazil. Journal of Helminthology, vol. 86, no. 4, pp. 440-445. http://dx.doi.org/10.1017/S0022149X11000666. PMid:22114910.

MENDONÇA, L.R., VEIGA, R.V., DATTOLI, V.C.C., FIGUEIREDO, C.A., FIACCONE, R., SANTOS, J., CRUZ, Á.A., RODRIGUES, L.C., COOPER, P.J., PONTES-DE-CARVALHO, L.C., BARRETO, M.L. and ALCANTARA-NEVES, N.M., 2012. Toxocara seropositivity, atopy and wheezing in children living in poor neighbourhoods in urban Latin American. PLoS Neglected Tropical Diseases, vol. 6, no. 11, pp. e1886. http:// dx.doi.org/10.1371/journal.pntd.0001886. PMid:23133689.

MOREIRA, G.M., TELMO, P.L., MENDONÇA, M., MOREIRA, A.N., MCBRIDE, A.J., SCAINI, C.J. and CONCEIÇÃO, F.R., 2014. Human toxocariasis: current advances in diagnostics, treatment, and interventions. Trends in Parasitology, vol. 30, no. 9, pp. 456-464. http://dx.doi.org/10.1016/j.pt.2014.07.003. PMid:25089038.

NOLLA, A.C. and CANTOS, G.A., 2005. Enteroparasitosis prevalence in food handlers, Florianópolis, SC. Revista da Sociedade Brasileira de Medicina Tropical, vol. 38, no. 6, pp. 524-525. http://dx.doi.org/10.1590/S0037-86822005000600015. PMid:16410931.

RITCHIE, L.S., 1948. An ether sedimentation technique for routine stool examination. Bulletin of the U.S. Army Medical Department. United States. Army. Medical Department, vol. 8, no. 4, pp. 326. PMid:18911509.

RUGAI, E., MATTOS, T. and BRISOLA, A.P., 1954. Nova técnica para isolar larvas de nematódeos das fezes - Modificação do Método de Baermann. Revista do Instituto Adolfo Lutz, vol. 14, no. 1, pp. 5-8. PMid:14372416.

SANTARÉM, V.A., LELI, F.N.C., RUBINSKY-ELEFANT, G. and GIUFFRIDA, R., 2011. Protective And risk factors for toxocariasis in children from two different social classes of Brazil. Revista do Instituto de Medicina Tropical de São Paulo, vol. 53, no. 2, pp. 67-72. http://dx.doi.org/10.1590/S003646652011000200002. PMid:21537752.
SANTOS, P.C., LEHMANN, L.M., LORENZI, C., HIRSCH, C., TELMO, P.L., MATTOS, G.T., et al, 2015. The seropositivity of Toxocara spp., antibodies in pregnant women attented at the university hospital in southern Brazil and the factors associated with infection. PLoS One, vol. 10, no. 7, pp. e0131058. http:// dx.doi.org/10.1371/journal.pone.0131058. PMid:26146833.

SAVIGNY, D.H., 1975. In vitro maintenance of Toxocara canis larvae and a simple method for the production of Toxocara ES antigen for use in serodiagnostic tests for visceral larva migrans. The Journal of Parasitology, vol. 61, no. 4, pp. 781-782. http:// dx.doi.org/10.2307/3279492. PMid:1165568.

SCHOENARDIE, E.R., SCAINI, C.J., BROD, C.S., PEPE, M.S., VILLELA, M.M., MCBRIDE, A.J.A., BORSUK, S. and BERNE, M.E., 2013. Seroprevalence of Toxocara infection in children from southern Brazil. The Journal of Parasitology, vol. 99, no. 3, pp. 537-539. http://dx.doi.org/10.1645/GE-3182. PMid:23738711.

SILVA, R.R., SIQUEIRA, R.V., SILVA, A.C., ANDRADE, G.F., MONTEIRO, M.R.P., GRASSELLI, C.S.M., et al., 2010. Prevalence of parasitic diseases and nutritional status of preschool children in municipal educational centers in the south of Minas Gerais state. Revista de Nutrição, vol. 35, no. 1, pp. 59-72.

SMITH, H. and NOORDIN, R., 2006. Diagnostic limitations and future trends in the serodiagnosis of human toxocarosis. In: C. V. Holland and H. V. Smith, eds. The enigmatic parasite. 1th ed. UK: Cabi Publishing. 324 p.

SMITH, P.K., KROHN, R.I., HERMANSON, G.T., MALLIA, A.K., GARTNER, F.H., PROVENZANO, M.D., FUJIMOTO, E.K., GOEKE, N.M., OLSON, B.J. and KLENK, D.C., 1985. Measurement of protein using bicinchoninic acid. Analytical Biochemistry, vol. 150, no. 1, pp. 76-85. http://dx.doi. org/10.1016/0003-2697(85)90442-7. PMid:3843705.

SOUZA, R.F., DATTOLI, V.C.C., MENDONÇA, L.R., JESUS, J.R., BAQUEIRO, T., SANTANA, C.C., SANTOS, N.M., BARROUIN-MELO, S.M. and ALCANTARA-NEVES, N.M., 2011. Prevalence and risk factors of human infection by Toxocara canis in Salvador, state of Bahia, Brazil. Revista da Sociedade Brasileira de Medicina Tropical, vol. 44, no. 4, pp. 516-519. http:// dx.doi.org/10.1590/S0037-86822011000400024. PMid:21860903.

VASCONCELOS, I.A.B., OLIVEIRA, J.W., CABRAL, F.R.F., COUTINHO, H.D.M. and MENEZES, I.R.A., 2011. Prevalência de parasitoses intestinais entre crianças de 4-12 anos no Crato, estado do Ceará: um problema recorrente de saúde pública. Acta Scientiarum. Health Sciences., vol. 33, no. 1, pp. 35-41.

WORLD HEALTH ORGANIZATION - WHO, 2017 [viewed 10 March 2017]. Water related diseases [online]. Geneva: WHO. Available from: http://www.who.int/water_sanitation_health/ diseases/ascariasis/en/ 